\title{
PRODUCTION TECHNOLOGY AND PROBLEMS OF THE HANDLOOM TEXTILE UNITS: A CASE STUDY ON THE SINGPHOS OF ASSAM
}

\author{
Kaberi Hazarika \\ Research scholar, Department of economics, Dibrugarh University, Assam, India
}

\begin{abstract}
Handloom weaving is the second largest and the most essential cottage industry after agriculture in India and it also provides the highest employment opportunities to the rural people. The present paper aims to study about the production behavior and problems of the handloom units of Singphos of the sample region. In this paper CobbDouglas production function is used to represent the production technology of the handloom units. $R^{2}$ indicates that about 67 per cent of the variation in the output is explained by the labour and capital. By using one tailed T test on the parameter it is found that handloom units are reveals constant returns to scale.
\end{abstract}

Key words: Cobb- Douglas, production function, returns to scale.

Cite this Article: Kaberi Hazarika, Production Technology and Problems of the Handloom Textile Units: A Case Study on the Singphos of Assam, International Journal of Management, 11(12), 2020, pp. 2020-2029.

http://iaeme.com/Home/issue/IJM?Volume=11\&Issue $=12$

\section{INTRODUCTION}

Handloom industry constitutes to be the foremost handicraft industry in India. This industry, like a tradition and a craft, has been handed down from generation to generation. Traditionally, it has been a momentous non-agricultural flourishing industry in the country. In the perception of employment, handloom weaving provides the highest employment chance to the rural people. After agriculture, handloom weaving is the chief and the crucial cottage industry in India. This industry is one of the labour intensive and tradition oriented industries of India. Handloom industry uses agricultural produce as its basic raw material. This industry provides direct and indirect employment to more than 43 lakhs weavers and allied workers, which are basically from the SC/ST, backward and minority community. This sector has been continued by transferring of skills from one generation to another.

Tabulated data summarized below has been shown the present status handloom industry in Assam: 
Production Technology and Problems of the Handloom Textile Units: A Case Study on the Singphos of Assam

Table 1 Distribution of handloom worker household by type

\begin{tabular}{|c|c|c|c|}
\hline State/ Country & Rural & Urban & Total households \\
\hline Assam & 1252188 & 17318 & 1269506 \\
\hline India & 2748445 & 396394 & 3144839 \\
\hline
\end{tabular}

Source: $4^{\text {th }}$ Handloom Census of India, 2019-20

As per the $4^{\text {th }}$ Handloom Census of India, the above data implies the distribution of handloom worker household in Assam and India. In Assam there are 1269506 nos. of handloom worker household. Out of this, 1252188 nos. household are in rural area and 17318 nos. are in urban area. In all over India there are 3144839 nos. of handloom worker household. Out of this 2748445 nos. are in rural and 396394 nos. are in urban area. The data reveals that most of the hand loom workers of Assam belong to rural areas and the picture is same for India as a whole.

Table 2 Total work force by the type gender

\begin{tabular}{|c|c|c|c|}
\hline State/ Country & Male weaver & Female weaver & Transgender \\
\hline Assam & 75587 & 1031717 & 124 \\
\hline India & 759149 & 1914499 & 243 \\
\hline
\end{tabular}

Source: $4^{\text {th }}$ Handloom Census of India, 2019-20

Regarding the gender distribution of total workforce of handloom workers in Assam, 75587 nos. are male weavers, 1031717 nos. are female weavers and 124 nos. transgender category weavers, whereas in India 759149 nos. are male weavers 1914499 nos. are female weavers and 243 nos. are transgender category weavers. The data implies that number of female weavers is more as compared to the male counterparts not only in Assam but also in India.

Table 3 Distribution of handloom worker households by social group

\begin{tabular}{|c|c|c|c|c|c|}
\hline State & SC & ST & OBC & OTHERS & TOTAL \\
\hline Assam & 204433 & 237286 & 425986 & 401801 & 1269506 \\
\hline India & 448737 & 601661 & 1055882 & 1038559 & 3144839 \\
\hline
\end{tabular}

Source: $4^{\text {th }}$ Handloom Census of India 2019-20

The above table represents the data of distribution of handloom workers household by social group. Here, the handloom workers belong to different types of social group i.e. SC, ST and OBC etc. From the data point of view there are 1269506 nos. of handloom weavers' household in Assam. Out of this, 204433 nos. are SC (Scheduled caste) group, 237286 nos. are ST (Scheduled tribe) group, 425986 nos. are in OBC (Other Backward Class) group and rests belong to other class or social group of people. On the other hand, in case of India, out of total 3144839 nos. handloom household, 448737 nos. are SC, 601661 nos. are ST and 1055882 nos. belong to OBC social group of people. From the above data, it is found that people of OBC group are dominantly associated with handloom industry as compared to the other social classes of people.

The Singpho are one of the native communities inhabited in Assam and Arunachal Pradesh (Borah, 2016). As per 2011 census, there are 7958 numbers of Singpho people comprising with 3999 males and 3959 females in complete North Eastern Region (Machey, 2018). In Assam, Singphos are commonly inhabits in Tinsukia district of Assam. Weaving activities are tradition of Singpho women and they are skilled weaver possessing a strong sense of design. In every Singpho household there is at least one or more than one loom. They employ themselves in these activities from their adult age. The women weavers have amazing talent and skills that comprise amalgamating different colors and crafting complicated designs. There are all sorts of costumes that a Singpho tribe member wears in a lifetime - and every outfit is hand-woven. 
The dress worn out by the Singpho tribe is very traditional, up till now stylish (Ningkhee,2008; Singpho, 2003). Their handloom outputs and looms are of incomparable font. Their conventional crafts and combination of colour on the clothes are unrivaled from the other communities' (e.g., Missing, Tai-Phake) clothes and also from machine made clothes. That is why the Singphos' handloom products are in a significant position in the open market and its demand is also high.

Major textile items produced traditionally by the Singpho community weavers in the sample region:

Table 4 Textile item, size \& uses

\begin{tabular}{|l|l|l|l|}
\hline $\begin{array}{c}\text { Sl. } \\
\text { No }\end{array}$ & \multicolumn{1}{|c|}{ Name } & $\begin{array}{c}\text { Approx } \\
\text { size in } \\
\text { square } \\
\text { meter }\end{array}$ & \\
\hline 1 & Bukang & $1.35 \times 0.90$ & $\begin{array}{l}\text { It is worn by women to wrap the lower part of the body from } \\
\text { waist down to the ankles. }\end{array}$ \\
\hline 2 & Nunguat & $3.25 \times 0.70$ & $\begin{array}{l}\text { It mostly used on top of the Bukang, covering the breasts and } \\
\text { upper segment of the body. }\end{array}$ \\
\hline 3 & $\begin{array}{l}\text { Tatot } \\
\text { bombham }\end{array}$ & $0.40 \times 3.00$ & It is used as headgear by the men and women. \\
\hline 4 & $\begin{array}{l}\text { Baka or } \\
\text { Lissabau }\end{array}$ & $1.25 \times 0.90$ & $\begin{array}{l}\text { Man use to cover the lower part of the body from waist down to } \\
\text { the ankles. }\end{array}$ \\
\hline 5 & Bhapai & $2.75 \times 1.25$ & Usually it is worn for religious purposes. \\
\hline
\end{tabular}

Source: Data collected during field survey

\subsection{Types of Looms}

The looms that have been used in different parts of Assam includes mainly:

- Loin (Kokalat-Bandha) loom.

- Throw-Shuttle (Hat Makur) loom.

- Pit (Hat-Makur-Mati) loom.

- Fly shuttle (Ura-Makur hal) loom.

The Loin loom and throw-shuttle loom (also called country loom) constitute the traditional type of loom in Assam. These looms have very simple devices, but both types possess some special characteristics. The fly shuttle loom was not extensively used in rural homes of Assam in ancient times. A brief description of the looms used traditionally in Assam is presented below

Loin-loom -This type of loom is the commonly used in the hill areas of Assam. This loom is very simple and easy to erect and dismantle. The concept texture of the cloth woven in a loin loom and its beautiful designs are the most important factor. That is why loin-loom has still not lost its popularity. This type of loin-loom is widely used by the hill tribes not only of North Eastern region of India but also in entire country. In fact, it is a part and parcel of the tradition of tribal textile. In the plain areas, it is still retained to some extent, by groups of people which are migrated from the hills in the past i.e. Singpho, Tai-Phakes etc. This type of loom has no frame or super structure, but it consists of two vertical bamboo poles between which another bamboo pole is kept horizontally. A few pieces of stout bamboo and wooden rods of varying thickness with a wooden beating sword are used as the accessories of the loom.

Throw-shuttle loom - The throw shuttle loom is the most common, popular and traditional loom used by all communities in the plains of Assam. The required instruments for the existing throw-shuttle loom are very simple and can easily be made out of traditional materials, mostly 
bamboo and wood. As such it is easily accessible to the rural folk of Assam. The frame on which, the loom is suspended consists of stout posts which are driven into the ground forming a rectangle. The posts are joined at the top by cross beams. The other parts of the loom are the warp and cloth beams, reed, slay, pulleys treadles, temples, shuttle etc.

Fly-shuttle loom - For commercial purpose of weaving practices the fly shuttle loom has entered in place of traditional weaving method at the homes in the rural areas of Assam. The ordinary throw-shuttle loom fitted with the fly-shuttle slay has however become popular among the weavers in the region. It has been marked that use of fly-shuttle loom is more popular among the weavers in the region. Factors like easy availability of fly-shuttle loom and the awareness of the rural people about the merits of weaving in this loom have contributed towards its popularity in the villages.

Pit loom - Now a day's pit loom is very rare practice of weaving. While using pit loom, the weaver keeps their position within a pit and loom is set up at the ground level. It is observed that this type of looms is also used among some tribal communities of Assam.

The Loin loom and throw-shuttle loom (also called country loom) compose the conventional type of loom in Assam. Both looms have very simple devices, with some special characteristics. The fly shuttle loom was not expansively used in rural homes of Assam.

Besides the loom itself, the major accessories traditionally used in weaving in the region are -

Table 5 Different accessories of loom

\begin{tabular}{|l|l|l|l|}
\hline $\begin{array}{l}\text { Singpho } \\
\text { Name }\end{array}$ & $\begin{array}{l}\text { Assamses } \\
\text { Name }\end{array}$ & $\begin{array}{l}\text { English } \\
\text { Name }\end{array}$ & Uses \\
\hline Kung & Yatar & Charkha & It is widely used to win the bobbins for weaving. \\
\hline Liwin & Chereki & Spool & $\begin{array}{l}\text { It is comprised with a bamboo frame, used as a device to place } \\
\text { the hanks. }\end{array}$ \\
\hline Phum & Raas & Reed & The reed is a comb fixed on slay with a reed cap. \\
\hline Rilot & Mohura & Pirm & $\begin{array}{l}\text { It is used to wound the weft yarn and to pass through the division } \\
\text { of warp threads by means of shuttle. }\end{array}$ \\
\hline Dalim & Maku & Shuttle & It is used to pass the pick across the warp-shed. \\
\hline Sinat & Tulutha & $\begin{array}{l}\text { Warp } \\
\text { Beam }\end{array}$ & $\begin{array}{l}\text { The warp beam is used to wound the warp yarn and fitted to the } \\
\text { bottom at the back of the loom and which contains up to one } \\
\text { hundred meter warp yarn. }\end{array}$ \\
\hline $\begin{array}{l}\text { Sumbui } \\
\text { Chang }\end{array}$ & Durpati & Slay & Slay is a wooden frame proving two shuttle box. \\
\hline
\end{tabular}

Source: Data collected during field survey and some published books

\subsection{Objective}

Present study is focus on the production techonology and problems of the handloom units of the Singphos.

\section{DATA \& METHODOLOGY OF THE STUDY}

To achieve the cited objective researcher conducted a field survey among the Singpho community of Assam. In Assam, Singpho are mostly concentrated in the Margherita circle of the Tinsukia district. There are 25 Singpho inhabited villages in Margherita circle. Since, Population size of the Singpho is very small. Therefore, 40 per cent of the total villages are randomly taken for the study. From each of the sample villages 20 per cent of the total Singpho households are selected for the present study. For collecting primary data questionnaire methods are used and data are collected for fix one year 2018-2019. 
Present study used multistage stratified random sampling for collecting required information. Different stages of collecting information are -

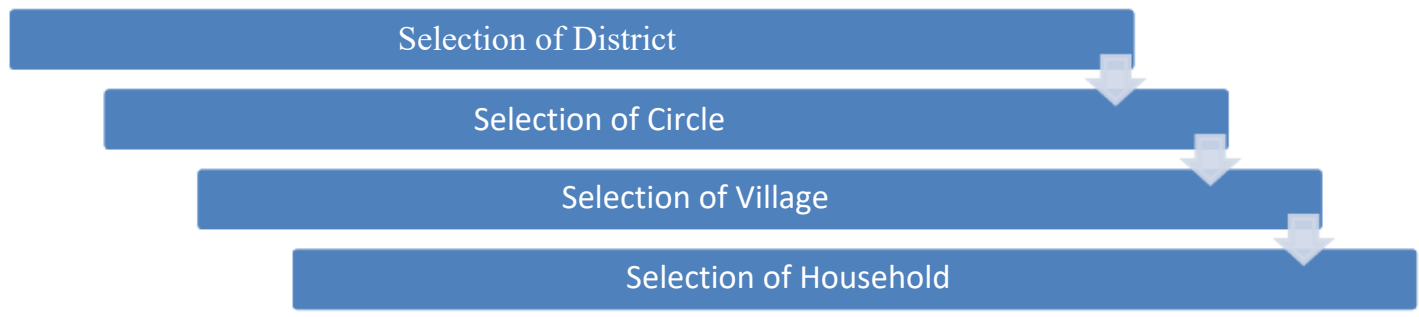

Figure 1

\section{RESULT AND DISCUSSIONS}

Factors of production are most important instruments for economic development and the productivities of these factors are directly related with the economic welfare of a nation. Now a day, the productivity has great importance in case of industrial development. Many economists suggest that higher level of productivity leads self sustaining economic GDP which has positive impact on the level of investment, employment and income. The factors productivity also improves both capital productivity and labour productivity. The empirical studies suggests that the productivity reduces the cost per output, improves product quality, increases wages of labour and gives more return on investment

\section{Production Function Analysis}

Production function is the technical relationship between inputs and outputs. Production is variation of physical inputs into physical output. It represents technology of a firm. Production behavior of the handloom units can be studied with the help of production function. In the present study Cobb-Douglas (Chowhdury, 2015; Gogoi, 2018; Husain S \& Islam, 2016) type production function is used to estimate the factors determining the variation of output.

Cobb-Douglas production function for the sample handloom units is as follows-

$$
Q=A L^{\beta 1} K^{\beta 2} e^{u}
$$

Where

$Q=$ Gross Value Added.

$\mathrm{A}=$ constant term.

$L=$ labour indices (at constant prices).

$\beta_{1}=$ elasticity of labour.

$K=$ Fixed capital indices (at constant prices).

$\beta_{2}=$ Elasticity of capital.

The non - linear model (1) is transformed into the following model:

$$
\ln _{e} Q=\ln _{e} A+\ln _{\mathrm{e}} \beta_{1} \mathrm{~L}+\ln _{e} \beta_{2} K+
$$

$u$

$$
=\beta_{0}+\beta_{1} \ln L+\beta_{2} \ln K+u
$$

(where $\left.\beta_{0}=\ln A\right)$

Now, applying the transformed model to the handloom units of Singphos', the following results are found - 
Production Technology and Problems of the Handloom Textile Units: A Case Study on the Singphos of Assam

Table 6 Estimated C-D production function for sample handloom units

\begin{tabular}{|l|l|l|}
\hline Regressor & Estimated coefficient & t value \\
\hline Labour & $0.69^{*}$ & 8.23 \\
\hline Capital & $0.65^{* *}$ & 2.38 \\
\hline Constant & -1.71 & -0.82 \\
\hline
\end{tabular}

$\mathrm{R}^{2}=0.67$

*Significant at $1 \%$ level.

**Significant at 5\% level.

From the above table it has been observed that elasticity of output with respect to the labour is 0.69 while the same with respect to the capital is 0.65 , which indicates that holding capital input constant, one per cent increase in labour input will result in output increment by 0.69 per cent and holding labour input constant, one per cent increase in capital input will result in output increment by 0.65 per cent. $\mathrm{R}^{2}$ indicates that about 67 per cent of the variation in the output is explained by the labour and capital.

\section{Returns to Scale}

Returns to scale is defined as the extent by which production changes as a outcome of a given proportionate change in the amounts of inputs used in the production. In the present study, one tailed t- test on the parameters (Gogoi, 2018) is used to calculate approximately the returns to scale of the sample handloom units. Regarding the increasing returns to scale the following hypothesis is to be tested:

Null Hypothesis

$$
\begin{array}{r}
H_{0}: \sum_{i=1}^{n} \beta_{i}=1 \\
H_{A}: \sum_{i=1}^{n} \beta_{i}>1
\end{array}
$$

Alternative Hypothesis

The t- statistics conducted using results such that -

Where,

$$
t \sum_{i=1}^{n} \beta_{i}=\frac{\beta_{1}+\beta_{2}-1}{S E\left(\beta_{1}+\beta_{2}\right)}
$$

Standard error of parameters estimated as -

$$
S E\left(\beta_{1}+\beta_{2}\right)=\sqrt{\operatorname{Var} \beta_{1}+\operatorname{Var} \beta_{2}+2 \operatorname{Cov}\left(\beta_{1} \beta_{2}\right)}
$$

By applying this formula returns to scale is found 1.345 with $\mathrm{t}$ score 1.33 , which is not statistically significant. Hence, null hypothesis is accepted. Therefore, it can be said that handloom units are reveals constant returns to scale.

\section{Problems of Handloom Units of Singphos of Assam}

Handloom industry gives gainful employment opportunities for women. In the study region every Singpho women made all their necessary clothes in their looms. It is seen that most of the handloom units efficiently use their available resources. There is a lot of potentiality to improve the performance of handloom industry. But it is unfortunate that handloom units face many problems, which will affect production of the industry.

\section{Lack of Technological Improvement}

Technological improvement of an industry helps in large scale of production and it also reduce cost of production of output. In the study region the outdated production technique are used in weaving activities. No any single handloom unit has used modern technique in the production process. Majority of handloom units use traditional loin loom and throw shuttle loom because these techniques are quite easy to operate for the weavers. And the productivity of such type of 
looms is much less than that of fly shuttle or power loom. Therefore, it reduced the output of the handloom units in physical terms. According to Choudhury the productivity of fly shuttle loom is two and half times higher than that of throw shuttle loom and productivity of power loom is six to eight times higher than that of fly shuttle loom.

\section{Problems related with marketing}

Efficient marketing system is very necessary for stimulating production. In the sample region the handloom units have been facing the problem of marketing their products. The lack of proper marketing facility is hinders for expansion of the size of production of the units. The weavers of this region have no opportunity to sell their products independently in the market. So, they sell their product to the local traders/intermediateries. It is found that such types of agent buy this product comparatively at a lower price and sell it to their customers at a higher price. Sometimes they cheat the weavers by not giving the actual remunerative prices for their products. Moreover the weavers have not any idea about the using of Ecommerce services to sell their products in the market.

\section{Competition with power looms}

Productivity of power loom is much higher than the traditional throw shuttle or loin loom. It also reduces the cost of production of their produces items as they cansell their products at a lower price which enhance the market demand of their products. Since the cost of production is higher in case of traditional looms the weavers/producer has charged comparatively a higher price as compared to the power looms produces output. Therefore the consumers demand for these items is quite higher than the traditional looms items.

\section{High Price of Raw Material}

Another problem faced by Singpho community weavers are higher price of raw material/yarn which increase the cost of production of their producing commodity. In Assam Singpho weavers are individually doing their handloom activities. So their scale of production is not in a large scale. Therefore they purchase small quantity of raw material from open market. And they do not derive the benefit of bulk buying of raw material as the large scale industry.

\section{Lack of Finance}

Finance is the main instrument of an industry to run their activities. According to Mathur (1979) every problem of the small producer concerning production or raw materials, qualities or marketing is ultimately a financial one. Success of a production operation depends on the availability of finance. In the sample region due to inadequate finance weavers could not upgrade their production technology rather they use traditional outdated techniques. It required much more capital to upgrade their traditional throw shuttle loom into fly shuttle one. The weavers of the study region have not use Muga and Silk yarn in the production activities. Because the price of these yarns are much higher than the other types of yarn like Thailan, Pokua, One ply, Zero ply etc. So they used these yarn alternatively.

\section{Training}

Training is very essential for application of advance technology in the production process. It will increase marginal productivity of the weavers. It also helps in large scale of production and reduces the cost of production. Training makes the weaver more efficient. In the study region most of the weavers do not take any formal training. They learn weaving activity from their elders, family members and relatives. They usually applied traditional methods of production which are low productive. 


\section{Market Channels}

Market channels are very essential for moving the product producer to final consumer. A proper market channels helps the industry to produce and sell more product to the consumers. Singphos are very artistic people and they weave very wonderful items in their looms. But unfortunately producers/weavers have faced the problem such as absence of proper market channels for selling their products at local as well as international market. It affects the weavers to get actual benefit.

\section{Subsistence Level of Production}

The Singpho women are traditionally engaged in weaving activity. Most of the Singpho weavers have one or more looms in their household. They made all their necessary items in their looms. In the sample region most of the weavers produces a subsistence level of handloom output which are used for domestic consumption. A few weavers produce a large scale of output. They also use such output in domestic and commercial purposes. Moreover, most of the weavers are engaged in handloom activities to spend their leisure time.

\section{Lack of Awareness About the Government Schemes}

Ministry of textile has taken various schemes to enhance handloom industry. For example the scheme under the yarn supply. The yarns are supplied at mill gate price to weavers, And under MUDRA loan the capital and term loans are provided through bank at 6 per cent interest rate etc. These types of schemes help to run handloom activity. But the weavers of the sample region do not have any awareness about these governments under taking schemes. They run their handloom activity through their surplus income.

\section{Knowledge About Prevailing Market Condition}

For the producer perspectives it is important to know about the prevailing market condition otherwise producer do not reap the actual benefit from their business. In the study region weavers have not knowledge about the prevailing market condition. After completing weaving they sell their product in the local market or middleman. Even most of the weavers do not aware about the actual market price of their product. Therefore, sometimes they do not get actual remunerative price of their product.

\section{Lack of Advertisement}

There is no proper scope to promote their producing product at national or international market Most of the weavers sell their product to the local traders and get less benefit from their handlooms activities. Moreover, most of the weavers are uneducated. They are not aware of the various government schemes which will give an opportunity to the weavers to promote their products in international market.

\section{Education}

Education is the most important tools for improved the marginal skill of the weavers. It helps the application of modern technique in the production process, deriving the benefit of financial grant from government, information about foreign as well as domestic market condition. In the study region most of the weavers are illiterate. They are not capable of adopting modern techniques in production activities; they do not get any information regarding various schemes which are taken by the government for up gradation of handloom industry in Assam. Therefore it will reduce output in quantity terms. 


\section{Charges Higher Level of Price}

Singphos' traditional clothes have a unique character. Because of their uniqueness quality and their traditional embroidery they captured a remarkable position in the market as compared to the other items. During the field survey it is found that there emerges some product which came from different parts of the country to the market. This machine made items had charged a lower price than Singphos' traditional clothes. And most of the customers are not aware of the features of the traditional handloom items. So, it affects the growth of traditional handloom industry.

\section{Lack of Awareness About the Government Schemes}

Ministry of textile has taken various schemes to enhance handloom industry. For example the scheme under the yarn supply. The yarns are supplied at mill gate price to weavers, And under MUDRA loan the capital and term loans are provided through bank at 6 per cent interest rate etc. These types of schemes help to run handloom activity. But the weavers of the sample region do not have any awareness about these governments under taking schemes. They run their handloom activity through their surplus income.

\section{Lack of Coordination}

All the Singpho women are indigenous weaver and all of them are engaged in weaving activity. In the study region all the weavers are doing their handloom activity individually. No any master weavers for managing handloom activity jointly in group as there is lack of coordination among the weavers. So the weavers buy small quantity of yarn from open market at a higher price and had not derived benefit of bulk buying.

\section{Findings}

- Output elasticity with respect to labour and capital are 0.69 and 0.65 .

- $\mathrm{R}^{2}$ indicates that about 67 per cent of the variation in the output is explained by the labour and capital.

- Handloom units of the study region are reveals constant returns to scale.

\section{CONCLUSIONS}

Weaving activities and producing handloom output of Singphos have some unique characteristics which are separate from the other tribal communities. Hence their handloom output has taken a remarkable position in domestic as well as international market and their demand also high as compared to the other textile. But these weaving units/weavers have not use modern technique in the production process also textile units are facing the problem of marketing their product. In Assam Singpho handloom weavers are individually doing their handloom activities. Due to lack of adequate capital they have not use silk, muga etc yarn. If these problems are removed as per their requirement and government policy implication successfully than it will definitely improve the performance of these handlooms units and get a remarkable position in the global market.

\section{ACKNOWLEDGEMENT}

I acknowledge my sincere thanks to Professor Deb Kumar Chakraborty sir and weaver's households for their support and co operation. 
Production Technology and Problems of the Handloom Textile Units: A Case Study on the Singphos of Assam

\section{REFERENCES}

[1] Boah, K. C.(2016). The Singphos: A demographic profile. Field data based research work .Department of Economics, Dibrugarh University, Dibrugarh

[2] Chowhdury, M.S.R. \& Islam, J.(2015). An analysis of production function of readymade garments industry in Bangladesh: A case study text-town group limited, International Journal of African and Asian Studies, 14. Forth all India handloom census 2019-20, Ministry of textiles, government of India.

[3] Gogoi, M. (2018). Production behavior and technical efficiency of organic tea growers: a case study in Dibrugarh district of Assam. M.Phil Dissertation, Dibrugarh university, Dibrugarh.

[4] Husain, S. \& Islam, S. (2016). A test for c-d production functions in manufacturing sector: the case of Bangladesh, International Journal of Business and Economic Research, vol. 5(5), 149154.

[5] Khatoon, S. (2016). Make in India: A platform to Indian handloom market, IOSR Journal of Business and Management, 18(9), 36 - 40.

[6] Manonmani, M. (1013). A stochastic frontier production function approach to indian textile industry, Indian Journal of Industrial Relation, 48(4), 703 -710.

[7] Madhavan, M. \& Kumaravel, M.(2014). A study on capacity utilization of indian industries, research revolution, International Journal of Social Science and Management, 2(11), 16 - 20.

[8] Machey, A. (2018). Socio Economic characteristic and Fertility behavior of the Singphos: A study of Assam and Arunachal Pradesh, Ph.D Thesis, Dibrugarh University, Dibrugarh.

[9] Ningkhee, R. (2008). Singpho samaj aru sabhayata, published by folk cultural research centre of north eastern India, Nagaon.

[10] Phukan, R. (2012). Handloom weaving in Assam: Problem and prospect, Global Journal of Human Social Science, 12( 8).

[11] Sastry, D. U.(1980). Capacity utilization in the cotton mill industry in India, Indian Economic Review, 15(1), 1 -28.

[12] Singpho, M.(2003). Shapawng yawng manau poi, Shapawng yawng India, Lekhapani, Tinsukia district, Assam. 